\title{
Spatial Variation of Livestock Distribution in Erbil Governorate
}

\author{
Saadoon Dhahir Khalaf Al Dulaimi \\ Department of Geography, College of Education for Humanities, University of Anbar, Iraq \\ ed.saadoun.zahir@uoanbar.edu.iq
}

\begin{abstract}
KEYWORDS: $\quad$ Geographical Distribution, Cows, Sheep, Goats, Erbil, Factors.
\end{abstract}
Crossref doi https://doi.org/10.51345/.v33i1.471.g261

\begin{abstract}
:
This research dealt with the study of the spatial variation of livestock (cows, sheep, goats) in the districts of Erbil governorates and There appeared a discrepancy between those districts in the number of cows, sheep and goats. The different distribution of livestock is due to natural and human factors that led to the difference in numbers between the districts of Erbil Governorate. Where the number of cows in Erbil governorate reached (93029) for the year 2021 and (631381) of sheep for the same year, and the number of goats reached (386934) for the year 2021. These animals are raised for their meat, milk, wool and skins that benefit the residents of the study areas. The quantities of its production may be outside the boundaries of the study area, and the research concluded that natural factors have an effective role in the variation of livestock, although human factors have a role in that variation in all its aspects. Also, livestock faced a number of natural and human problems that led to a different distribution according to the districts. The study recommends providing breeds of good production with the provision of feed necessary for animal husbandry with the introduction of vaccines and treatments of good varieties with the increase of veterinary centers in order to increase the number of livestock in the study area.
\end{abstract}


التباين المكابي لتوزيع الثروة الحيوانية في محافظة أربيل

\author{
سعدون ظاهر خلف الدليمي \\ قسم الجغرافيا، كلية التربية للعلوم الإنسانية، جامعة الأنبار، العراق \\ ed.saadoun.zahir@uoanbar.edu.iq
}

الكلمات المفتاحية | الثوزيع الجخر افي، الأبقار، الأغنام، الماعز ، أربيل، العوامل.

Crossref doi https://doi.org/10.51345/.v33i1.471.g261

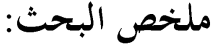

تناول هذا البحث دراسة التباين المكاني للثروة الحيوانية (الابقار، الاغنام، الماعز) في اقضية محافظة اربيل وظهر هناك تباين ما بين

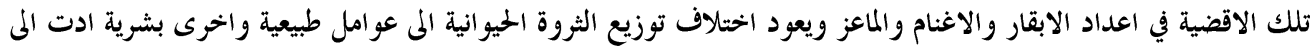

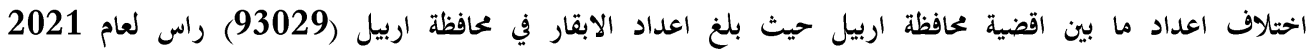

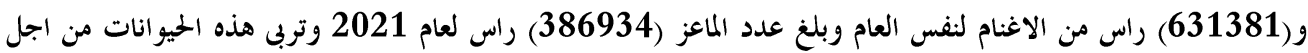

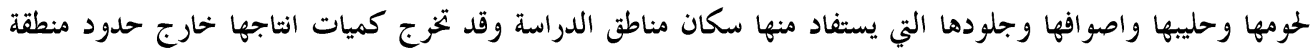

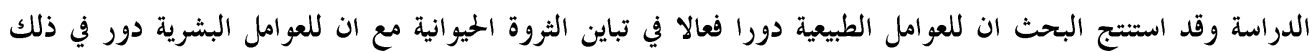

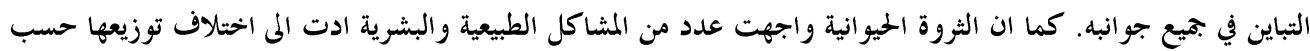

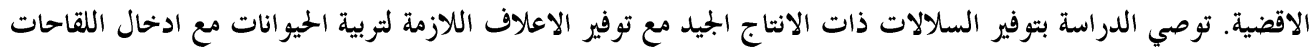

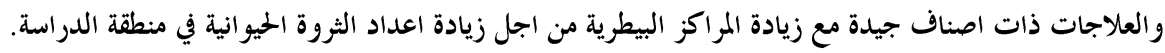

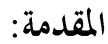

تمتلك منطقة الدراسة اعداد متنوعة من الثروة الحيوانية والتي توفر احتياجات السكان من اللحوم والحليب اضافة الم مد الصناعة ببعض المواد الاولية كالجلود والاصواف كما اها تمد الارض بسمادها

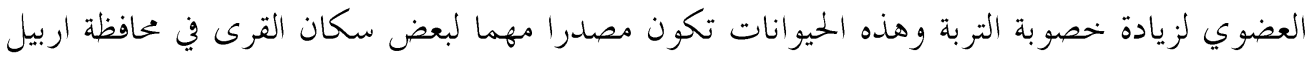
وسوف نتطرق في هذا البحث عن الابقار والاغنام والماعز موزعة على عشرة اقضية في محافظة اربيل وتباين توزيعها بين اقضية المحافظة في حيث انقسمت الدراسة الم ثلاث مباحث المبحث الاول تناول العو امل الجغرافية في محافظة اربيل اما المبحث الثناني انختص بالتوزيع الجغرافي للثروة الحيوانية في منطقة

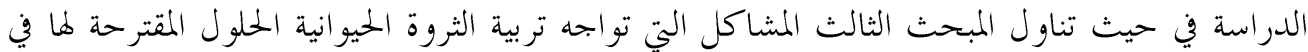
منطقة الدراسة ومن ثم الاستنتاجات و التوصيات. 


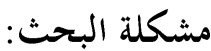

تشتمل مشكلة البحث في الاسئلة الاتية:

هل يوجد تباين في توزيع الثروة الحيو انية في محافظة اربيل؟

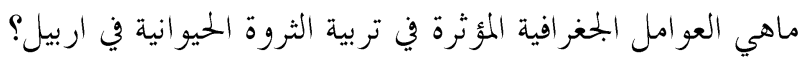
ماهي المشاكل التي تعاني منها الثروة الحيوانية؟ لمريج

\section{فرضية البحث: - n}

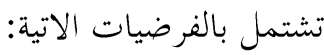

يو جاد تباين في توزيع الثروة الحيوانية

توجد العديد من العوامل التي تئثر في توزيع الثروة الحيوانية

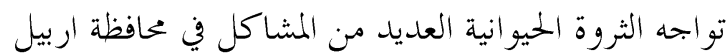

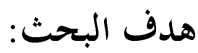

يهدف البحث الم دراسة التباين المكاني للثروة الحيوانية في اربيل

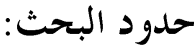

يشمل الموقع الفلكي والموقع الجغرافي:

الموقع الفلكي تقع محافظة اربيل بين دائرتي عرض (35,30 - 37,15) شمالا وبين خطي طول (45,05 -43,22) شرقا، اما موقعها الجغرافي تقع محافظة اربيل بالقسم الشمالي الشرقي من العراق

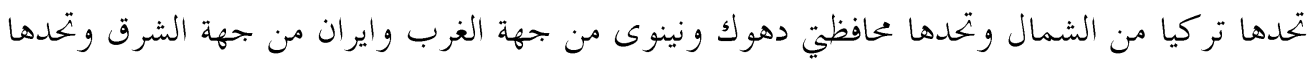

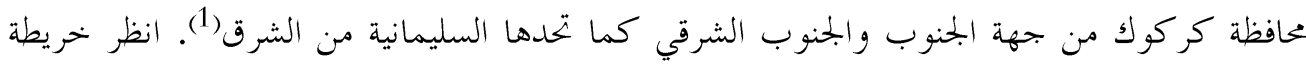

تبلغ مساحة محافظة أربيل (15969,56) كم2 وتشكل نسبة 3.6\% من مساحة العراق البالغة (438317) كم2، تتكون محافظة اربيل من عشرة اقضية انظر جدول (1) وخريطة (1).

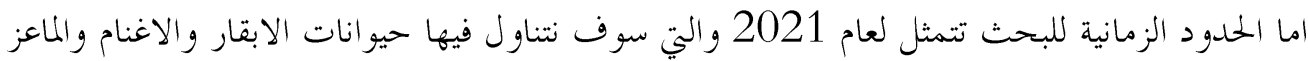
في اقضية محافظة اربيل. 
جدول (1) مساحة اقضية محافظة اربيل

\begin{tabular}{|c|c|c|}
\hline المساحة دونم & المساحة كم2 & الاقضية \\
\hline 909.378 & 2273.445 & سوران \\
\hline 810.057 & 2025.1425 & ميركه سور \\
\hline 491.845 & 1229.6125 & جومان \\
\hline 268.509 & 671.272 & راوندوز \\
\hline 824.349 & 2060.8725 & شقلاوة \\
\hline 257.000 & 642.5 & مركز أربيل \\
\hline 500.737 & 1251.8425 & سهل أربيل \\
\hline 891.300 & 2228.25 & كويه \\
\hline 344.525 & 861.3125 & خابات \\
\hline 1.090 .124 & 2725.31 & مخمور \\
\hline 6.387 .824 & 15969.56 & المجموع \\
\hline
\end{tabular}

المصدر: 1- اقليم كردستان العراق، رئاسة بجلس الوزراء، هيئة احصاء اقليم كردستان، بيانات غير منشورة، 2015، صل18.

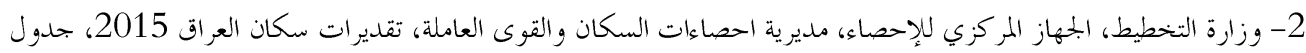
.56

خريطة (1) موقع محافظة أربيل من حيث العراق

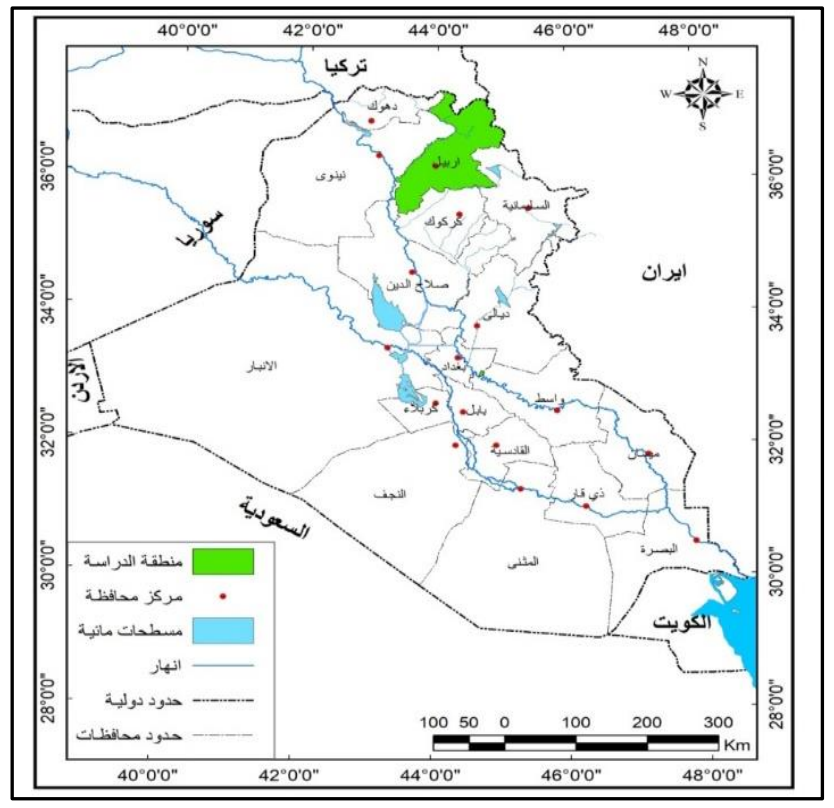


المصدر / بالاعتماد على: وزارة البلديات في إقليم كردستان، مديرية بلدية أربيل، قسم التصميم، بيانات غير منشورة،2021م

\section{المبحث الأول: العو امل الجغر افية المؤثرة في توزيع الثروة الحيوانية \\ اولا- العو امل الطبيعية:}

تعد دراسة العوامل الطبيعية في محافظة اربيل واحدة من اولويات دراسة هذا البحث لمعرفة خصائصها المؤثرة على توزيع الثروة الحيوانية وأثر كل عامل منها في تباين الثروة الحيوانية في منطقة الدراسة ومن

$$
\begin{aligned}
& \text { اهم هذه العو امل هي } \\
& \text { 1-التضاريس: }
\end{aligned}
$$

التضاريس واحدة من الخصائص الطبيعية والمؤثر في توزيع الثروة الحيوانية في منطقة الدراسة وتختلف تضاريس منطقة الدراسة من مكان الى اخر و ان دلَ هذا على شيء فانه يدل على اختلاف توزيع الثروة الحيوانية في محافظة اربيل ويمكن ان تقسم منطقة الدراسة الى اربعة مناطق وهي كالاتي: أ-المنطقة الجبلية المعقدة الالتو اء ب_المنطقة الجبلية بسيطة الالتو اء ت_المنطقة شبه الجبلية ث-منطقة السهول الجبلية أ- تعد منطقة الجبال معقدة الالتواء من اكثر الوحدات التضاريسية تصعيدا في تلك المناطق مع انعدام الاراضي السهلية فيها وزيادة اعداد الوديان والممرات الضيقة ما بين سلاسلها وتمتد هذه السلاسل في الجنوب الشرقي من محافظة اربيل، وان اغلب صخورها نارية ومتحولة شديدة الصلابة وتتكون من بحموعة من السلاسل مثل جبال حصا روس و كاروخ و سد ميران ويتباين ارتفاعها ما بين (2000-

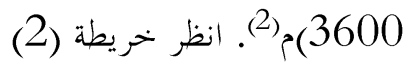

ب-المنطقة الجبلية بسيطة الالتواء: تعد هذه الجبال اقل ارتفاعا من الجبال المعقدة حيث يصل ارتفاعها الى (2000) م و تقسم الى بحموعتين هما الشمالية وتضم جبال كر كوك والحرير ويتراوح ارتفاعها بين (1440-2000) م اما الجنوبية يتراوح ارتفاعها بين (1000-1550) م وهي تضم جبال هيب سلطان و جبال بيرمام وباو جي. ت-منطقة شبه الجبلية: تعد هذه المنطقة اقل ارتفاعا من المناطق الاخرى المعقدة. فهي تمتاز في انبساط اراضيها وقلة ارتفاعها و لا يتعدى ارتفاعها (1000) م فلا تخلو هذه المنطقة من بعض التلال والمرتفعات 
مثل سلاسل مرتفعات زوركة زراو وقرة جوغ في قضاء خخمور ومرتفعات دميرداغ في خابات ومن ميزات هذه المنطقة هي وجود السهول الواسعة التي تضم عدد من القرى والمستوطنات البشرية وابرز

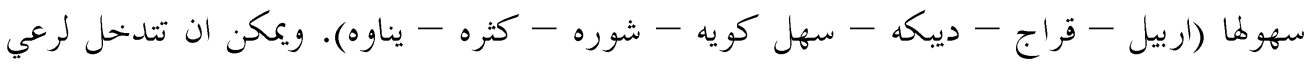
بعض الحيو انات فيها. ث-منطقة السهول الجبلية: وهي من اهم المناطق السهلية وتقع هذه المنطقة بين الجبال المعقدة الالتوائية

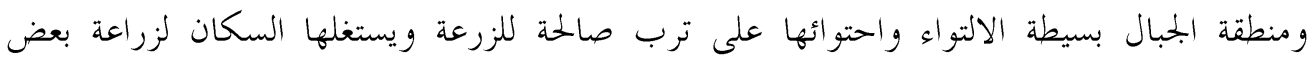
المحاصيل الزراعية لغذاء الانسان ومن ثم للحيو ان ويقطن فيها بعض القرى كما في سهل ديانا وحرير وتعد منطقة جيدة لتربية الحيوانات وذلك لوجود الاعلاف وملائمة الظروف فيها.

2

للمناخ اثر فعال على الثروة الحيو انية في كل مكان فهو يؤثر على توزيعها من حيث اثرة على توفير الاعلاف وارتفاع وانخفاض في درجات الحرارة والامطار كما يؤثر على تربيتها بين اجزاء منطقة الدراسة. ان المناخ السائد في منطقة الدراسة هو المناخ القاري، حيث ان المدى الحراري السنوي المرتفع نسبيا ويسجل اعلى درجة للحرارة في شهر تموز(3). حيث تقسم عناصر المناخ المى ما يأتي:

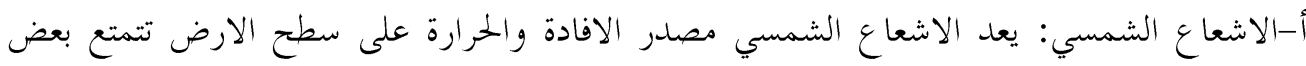
اجزاء منطقة الدراسة بساعات سطوع الشمس تزيد من تنشيط فيتامين (D) الضروري لبناء العظام

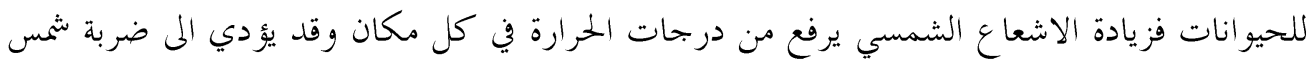
لبعض الحيوانات او قد تصاب ببعض الفطريات عند انخفاض اشعة الشمس فان الاشعاع الشمسي له ايجابيات و سلبيات. ب-درجة الحرارة: تعد درجة الحرارة واحدة من اهم عناصر المناخ المحدودة للزراعة ولتربية الثروة

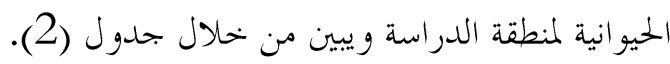
ان درجات الحرارة تختلف من شعار الى اخر في اجزاء منطقة الدراسة حيث تبين من الجحدول ان أبرد

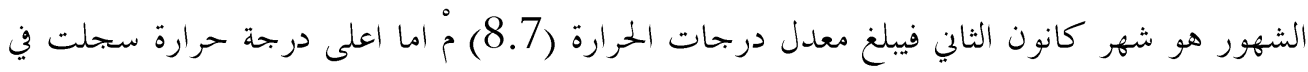

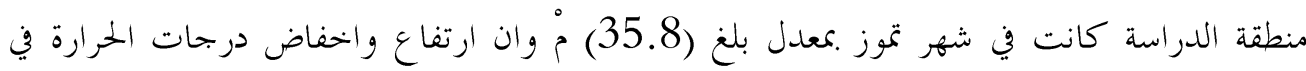
منطقة الدراسة له إثر على توزيع الثروة الحيوانية. 
ت الامطار: تعتبر واحدة من العناصر المناخية والمهمة في منطقة الدراسة لأذها تؤثر تأثير فعال في ظهور الاعشاب التي تتغذى عليها الثروة الحيوانية وذلك من خلال علاقة نمو الغطاء النباتي وتوفير الاحتياجات المائية اللازمة لنمو النبات. تختلف امطار منطقة الدراسة من مكان الى اخر حيث ان يزداد سقوط الامطار في مناطق الجبال العالية وينخفض في المناطق السهلية من منطقة الدراسة وان امطار منطقة الدراسة هي امطار إعصاريه. ان تواجد الامطار واعتدال درجات الحرارة ادى الى ضهور النباتات الطبيعية في منطقة الدراسة والتي يتغذى عليها الحيوان في المراعي وهذا عامل مشجع في زيادة الثروة الحيو انية في منطقة الدراسة. ومن خلال ملاحظة جدول (2) تبين ان مجموعة الامطار السنوية في منطقة الدراسة (401) ملم وهذه الكمية كافية لنمو النباتات التي يتغذى عليها الحيوان في جميع اجزاء منطقة الدراسة.

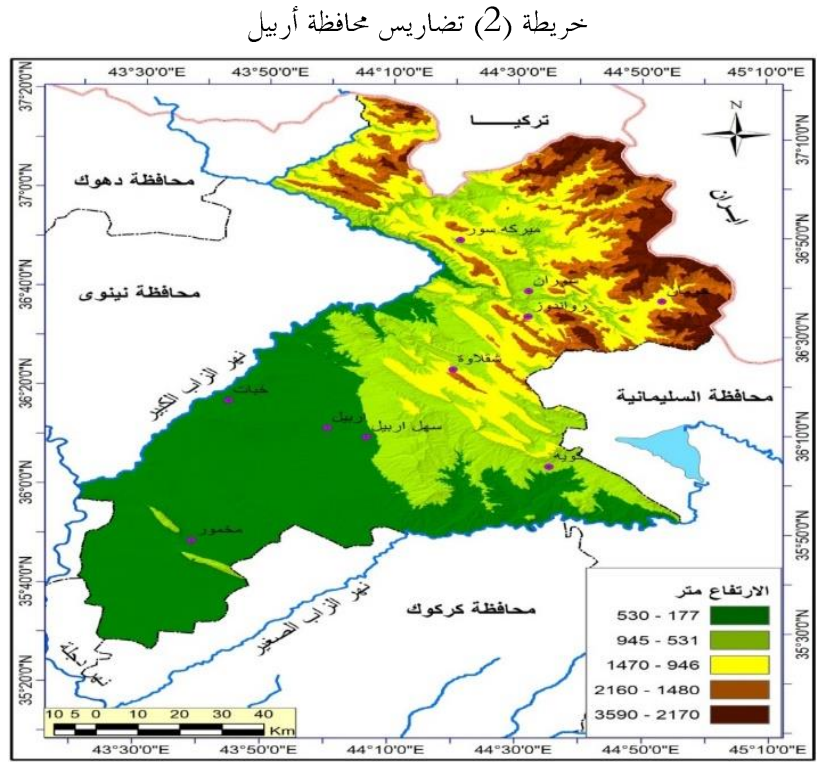

المصدر: بالاعتماد على: دائرة الإحصاء إقليم كردستان، محافظة أربيل، قسم التصميم، سجلات القسم، بيانات غير منشورة،2021م.

ثـالرطوبة النسبية: تعد الرطوبة النسبية واحدة من العناصر المناخية التي لها تأثير على حياة النباتات و الحيوان في منطقة الدراسة وان ارتفاعها وانخفاضها الشديد له تأثير على حياة الخيوانات و النباتات. ان معدل الرطوبة النسبية في ححافظة اربيل بلغ (50\%) حيث ان الرطوبة تنخفض في المناطق المرتفعة وترتفع في المناطق المنخفضة بسبب اختلاف درجات الحرارة في تلك المناطق كما ترتفع الرطوبة في فصل الشتاء 
وتنخفض في فصل الصيف لعدم سقوط الامطار في فصل الصيف وهذا له دور في توفير الجو الملائم للثروة الحيوانية في منطقة الدراسة.

ج-الرياح: تعد الرياح واحدة من عناصر المناخ المهمة لما له اهمية في درجات الحرارة والرطوبة النسبية في منطقة الدراسة وتتتلف سرعة الرياح واتجاهاها في اجزاء المنطقة وذلك حسب تضاريس محافظة اربيل المعقدة وحسب التحاه السلاسل الجبلية في بعض اجزاء منطقة الدراسة وتتراوح سرعة الرياح في منطقة الدراسة بين

(1.7-2.8) جثنا. للرياح اثار ايجابية على الثروة الحيوانية من خلال مد الحيوانات بالأوكسجين و النبات بثاني او كسيد الكاربون وبعض الايجابيات الاخرى فله اثار سلبية على الحيو انات والنبات حيث بـثيث ان للرياح عامل مهم في نقل بعض الامراض من مكان الى اخر اضافة نقل بعض التربة من مكان الى اخر و العو اصف الترابية تؤثر على الثروة الحيوانية وعلى غذائها من النباتات في منطقة الدراسة.

جدول (2) المعلات الشهرية والسنوية لدرجات الحرارة واشعة الشمس والامطار في محطة اربيل للمدة 1990 - 2021

\begin{tabular}{|c|c|c|c|c|c|c|c|c|c|c|c|c|c|c|}
\hline $\begin{array}{l}\overline{3} \\
\overline{3} \\
\overline{3} \\
\overline{3}\end{array}$ & $\begin{array}{l}\frac{y}{7} \\
. j \\
\bar{j} \\
j\end{array}$ & $\stackrel{]}{\sim}$ & ]. & 吾 & $\bar{\jmath}$. & 玨 & $\frac{1}{3}$ & 弯 & 霰 & $\sqrt[5]{7}$ & 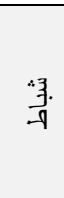 & $\begin{array}{l}y \\
3 \\
3 \\
\overline{3} \\
\overline{3} \\
y\end{array}$ & 变 & $\begin{array}{l}\overline{3} \\
3 \\
\lambda \\
:]\end{array}$ \\
\hline 27.06 & 14.5 & 20.6 & 30 & 36.7 & 41.6 & 41.9 & 38.4 & 34.7 & 24.4 & 19.1 & 14.2 & & 12.6 & العظمى إرة \\
\hline 14.7 & 5 & 9.9 & 17.1 & 21.7 & 26 & 26.5 & 23.2 & 17.9 & 12.2 & 7.9 & 4.4 & & 3.8 & الصغرى الحرة \\
\hline 21.7 & 9.8 & 15.2 & 24.3 & 30.4 & 35.2 & 35.8 & 32.4 & 26.1 & 19.2 & 13.7 & 9.8 & & 8.7 & الحرارة \\
\hline 8 & 4.5 & 5.6 & 7.8 & 10.10 & 11.2 & 11.4 & 11.5 & 9.4 & 7.3 & 6.6 & 5.9 & & 4.7 & الالشعاع \\
\hline 401 & 79 & 38 & 15 & 0.8 & 0 & 0.4 & 3 & 7 & 45 & 73 & 57 & & 83 & الامطار \\
\hline
\end{tabular}

المصدر: وزارة النقل والمواصلات، قسم الانواء الجوية، محطة اربيل، بيانات غير منشورة للمدة (1990-2021)

شكل (1) معدل درجات الحرارة والحرارة العظمى والصغرى في معطة اربيل للفترة 1990 - 2021 


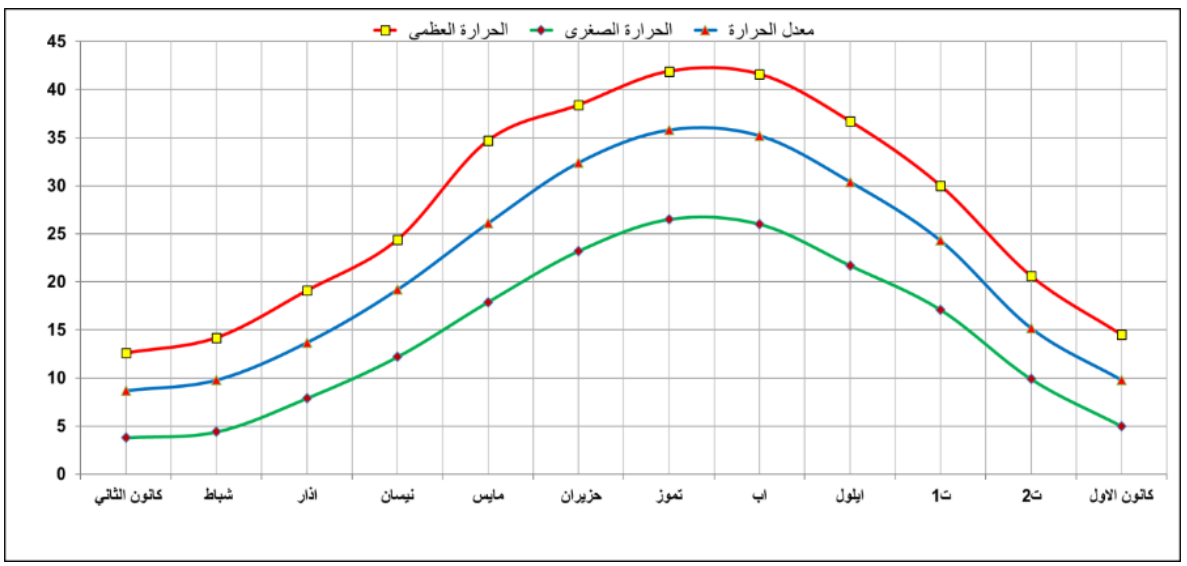

المصدر : من عمل الباحث بالاعتماد على جدول (2)
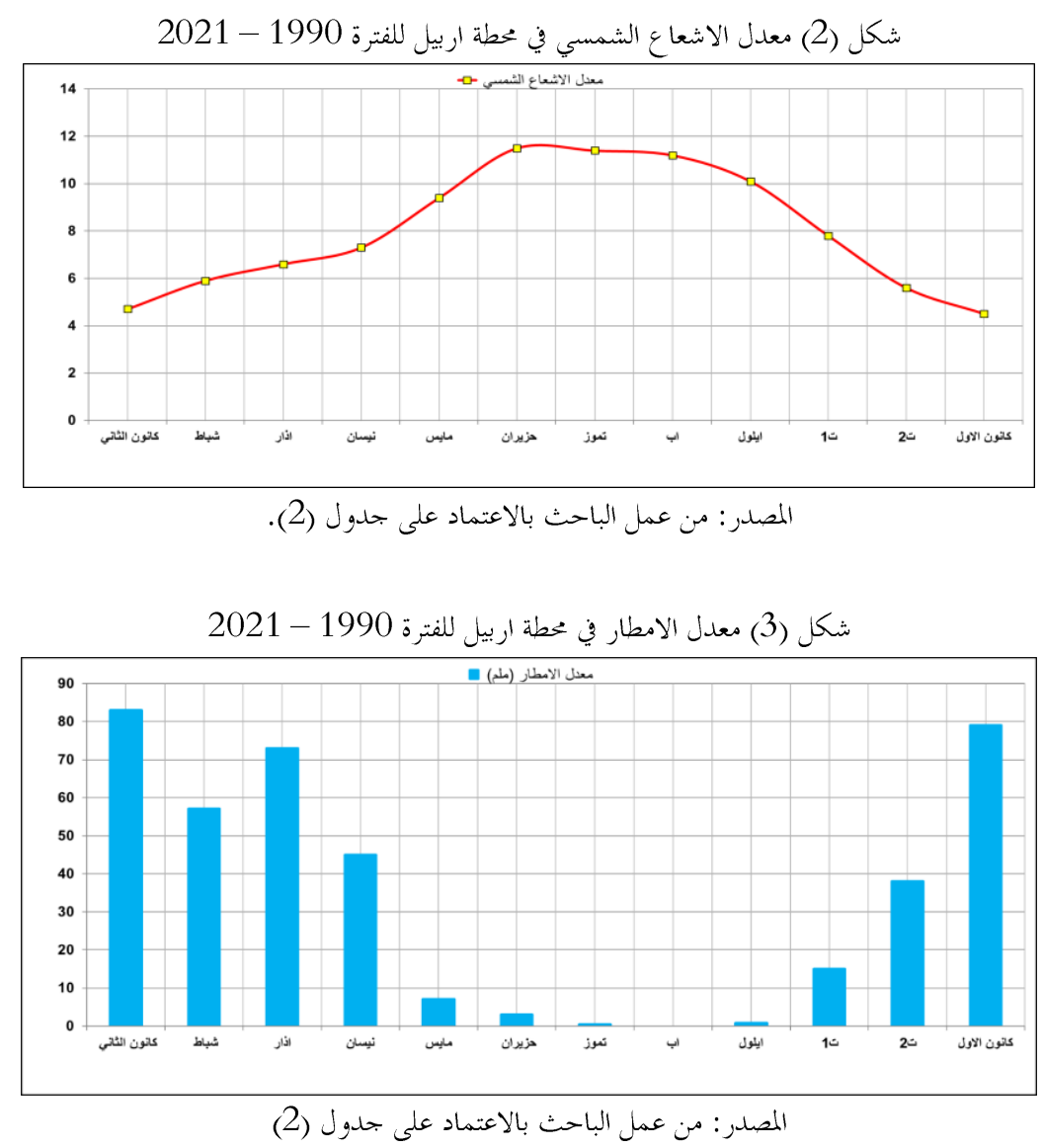
3-التربة: تعتبر التربة احدى العوامل الطبيعية الاساسية في توفير النباتات التي يتغذى عليها الحيوان في منطقة الدراسة. حيث ان التربة في منطقة الدراسة تختلف من مكان الى اخر حيث ينخفض سمك التربة على سفوح المرتفعات ويزداد في بطون الاودية وبعض السهول في منطقة الدراسة ولسمك التربة اهمية كبيرة في انبات النباتات التي تتغذى عليها الحيوانات في منطقة الدراسة حيث تتوفر انواع من التربة التي ينمو فيها النبات من اجل ان يتغذى عليها الحيوان واضافة الى تواجد كميات كافية من الامطار وعناصر المناخ الاخرى المساعدة في توفير النباتات التي تتغذى عليها حيوانات منطقة الدراسة وبكميات كافئية خاصة في فصل الشتاء والربيع وتقل النباتات الخضراء في فصل الصيف.

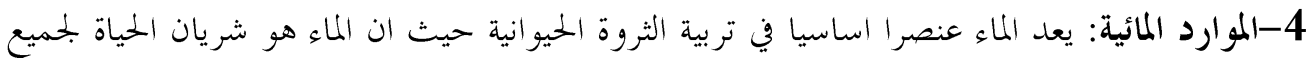
الكائنات الحية ولا حياة بدون الماء تتو اجد المياه في منطقة الدراسة بنوعين هي (المياه السطحية والمياه

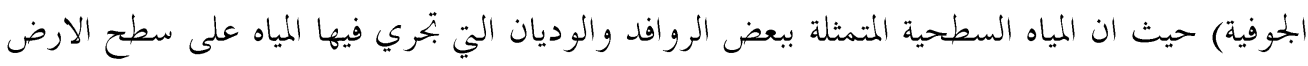

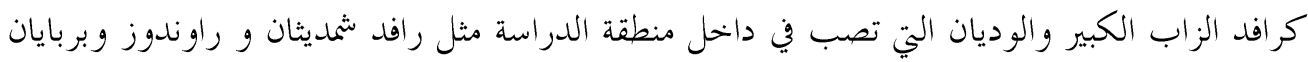

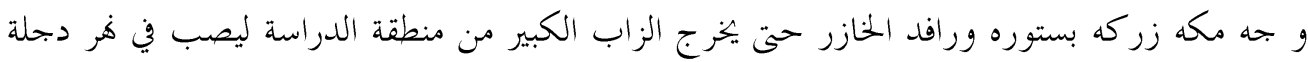

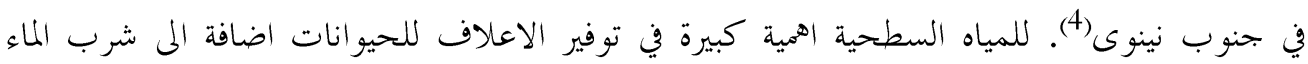
للحيو انات من اجل ديمومة الحياة للحيو انات والنباتات التي تتغذى عليها تلك الحيو انات اما المياه الجوفية لئية المتمثلة بالمياه التي تخرج من باطن الارض عن طريق العيون والينابيع والتي لها دور فعال في زراعة ونمو النباتات التي تتغذى عليها الثروة الحيو انية في منطقة الدراسة. تعد الامطار والثلوج المصدر الساس للمياه السطحية والجوفية في منطقة الدراسة وان الامطار الساقطة في منطقة الدراسة تتراوح بين (400-

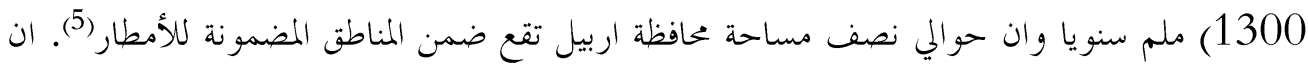

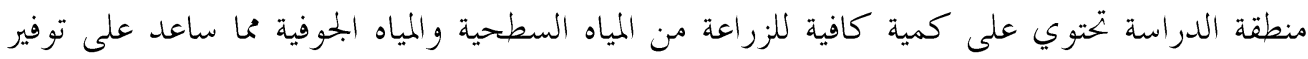
النباتات وخاصة في فصل الشتاء والربيع وذلك عن طريق زيادة كمية المياه السطحية والجوفية من مياه

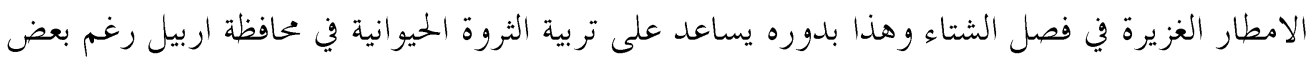
الصعو بات التي تواجهها 5-النبات الطبيعي: ان النبات الطبيعي هو احد العوامل المؤثرة في تربية الثروة الحيوانية في منطقة

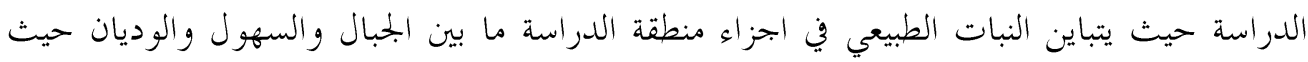

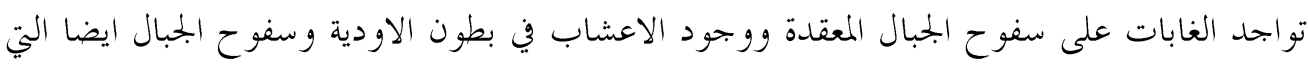
تتغذى عليها الحيوانات من اجل ديمومة حياها وزيادة انتاجها نوعا وكما وان اختلاف النباتات بين 
اجزاء منطقة الدراسة يعود الى اختلاف الترب وسمكها وتواجد العناصر المناخية الملائمة لتوفير النباتات الطبيعية التي تتغذى عليها الثروة الحيوانية في محافظة اربيل

\section{ثانيا : العو امل البشرية}

يعد السكان واحد من العناصر المهمة في تربية الثروة الحيوانية في اي مكان لانه هو من يقوم بتربية الثروة الخيو انية وتوفير ما تحتاجه من ماء واعلاف وتوفير المستلزمات الاخرى لتربية الثروة الخيوانية ويف نفس الوقت هو المستهلك للحوم والحليب ومشتقاته اضافة الى جلود واصواف تلك الحيوانات وان الانسان هو محور العملية الانتاجية لجميع الحيوانات في منطقة الدراسة ويمكن تقسيم العوامل البشرية المؤثرة على الثروة الحيوانية الى علدة أقسام:

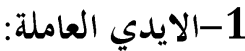

تعد الايدي العاملة من أبرز العوامل البشرية في تحقيق الانتاج الزراعي بشقيه النباتي والحيواني حيث المربي هو من يقوم بتوفير المأكل والمشرب والمأوى والعناية بالثروة الحيوانية. حيث ان مهما تطورت تربية الثروة الحيوانية لا يمكن الاستغناء عن الايدي العاملة في زراعة النباتات او في تربية الحيوانات فالإنسان هو من يقوم في تربية الحيوانات ورعايتها ومن ثم استهلاكها عن طريق ذبح قسم منها او يتغذى على منتوجاها من الحليب ومشتقاته. يختلف توزيع سكان منطقة الدراسة من مكان الى اخر فهم يتوزعون على عشرة اقضية كما موضح في جدول (3) حيث ان سكان منطقة الدراسة في تزايل مستمر حيث كان عدد سكان منطقة الدراسة (541456) نسمة في عام 1977 اما في عام 2010 فقد بلغ (1404743) نسمه فقد زاد سكان المحافظة الى ضعف ما كان في عام 1977 وان دل هذا على شيء فانه يدل على ان زيادة السكان في استمرار وهي هذا تحتاج الى الانشطة الزراعية بفرعيها النباتية والحيو انية فيجب رفع كفاءة الثروة الحيوانية من اجل توفير متطلبات السكان من المنتجات الحيوانية في منطقة الدراسة اما في عام 2021 فقد ارتفع عدد سكان منطقة الدراسة حتى اصبح (1944717) نسمة فقد اختلفت كثافات واعداد السكان بين اقضية منطقة الدراسة كما موضح في جدول (3) وخريطة (3)، وون ابرز المشاكل التي تواجه الايدي العاملة هي هجرة بعض المزارعين من الريف نهو المدن وذلك لوجود فرص عمل غير الزراعية من اجل كسب ربح اكبر مما كان يكصل عليه الفلاح في الريف من الزراعة في منطقة الدراسة. على الرغم من التطور الذي يكصل في اقليم شمال العراق عامة ومحافظة اربيل خاصة وان المزارعين ومربين الحيوانات مازالوا يعانون من مشاكل عديدة في تربية الثروة الحيوانية وقلة دعم الحلكومة المحلية 
للفلاح وهذا ما ادى الى عزوف بعض المزارعين عن تربية بعض الحيوانات وترك الريف والهجرة نهو المدن من اجل توفير فرص عيش أفضل مما كان علية في الريف.

جدول(3) حجم السكان ومساحات الاقضية لمحافظة أربيل لعام 2021م

\begin{tabular}{|c|c|c|c|}
\hline الكثافة السكانية نسمة /كم2 & المساحة كم2 & عدد السكان & الأقضية \\
\hline 77.9 & 2273.445 & 177158 & سوران \\
\hline 24.6 & 2025.1425 & 49774 & ميركه سور \\
\hline 24 & 1229.6125 & 29542 & جومان \\
\hline 35.8 & 671.272 & 24046 & راوندوز \\
\hline 68.9 & 2060.8725 & 142100 & شقلاوة \\
\hline 1.4 & 642.5 & 904858 & مركز اربيل \\
\hline 168.8 & 1251.8425 & 211263 & سهل اربيل \\
\hline 47.8 & 2228.25 & 106454 & كويه \\
\hline 121.5 & 861.3125 & 104720 & خبات \\
\hline 71 & 2725.31 & 194802 & مخمور \\
\hline 121.8 & 15969.56 & 1944717 & المجموع \\
\hline
\end{tabular}

المصدر / بالاعتماد على : وزارة التخطيط في الإقليم كردستان، دائرة الإحصاء، قسم التخطيط، بيانات غير منشورة، 2021م. 2-السياسة الزراعية: هي أحد فروع السياسة الاقتصادية للدولة، وهي خطة عمل تتوافق مع الظروف الاقتصادية لللوولة، وتضعها الحكومة، وتنفذ من خلال برامج واضحة ومحدودة تدف الى رفع المستوى المعاشي للدولة. وقدف السياسة الزراعية الى تحقيق الرفاهية الاقتصادية في محافظة اربيل من خلال التوزيع الامثل للسلع الزراعية للمستهلكين و كذلك التوزيع الامثل للموارد الانتاجية ما بين الاستعمالات البديلة (6) ان السياسة الزراعية هي تدخل الدولة من اجل تنمية القطاع الزراعي من خلال الاشراف ووضع الخطط لتوفير مستلزمات الانتاج الزراعي في خدمة النشاط الزراعي بشقيه النباتي والحيواني. لحد الان لم يكظى النشاط الزراعي في العراق بشكل عام ومحافظة اربيل بشكل خحاص بالأهمية من حيث السياسات الحكومية المتعاقبة ابتحاه النشاط الزراعي فهو نشاطا هامشيا في قوانين الدولة واغلب القرارات السياسية هي حبر على ورق بلدون تنفيذ على الواقع هذا ما ادى عدم توفير مستلزمات الفلاح ما يجتاجه من اجل زراعة وتربية الثروة الحيوانية في منطقة الدراسة بالشكل المطلوب كما هو في اغلب دول العالم المتطورة. و السياسة الزراعية اقسام عدة منها السياسة التسعيرية والسياسة الاستثمارية وسياسة التجارة الخارجية وسياسة توفير الغذاء وسياسة التسويقية وسياسة الماشية اين هذه السياسات من تربية الثروة الحيوانية فهذه السياسات غير مفصلة الا في قسم قليل جدا منها في اجزاء مختلفة من العراق عامه و منطقة الدراسة خحاصة. 


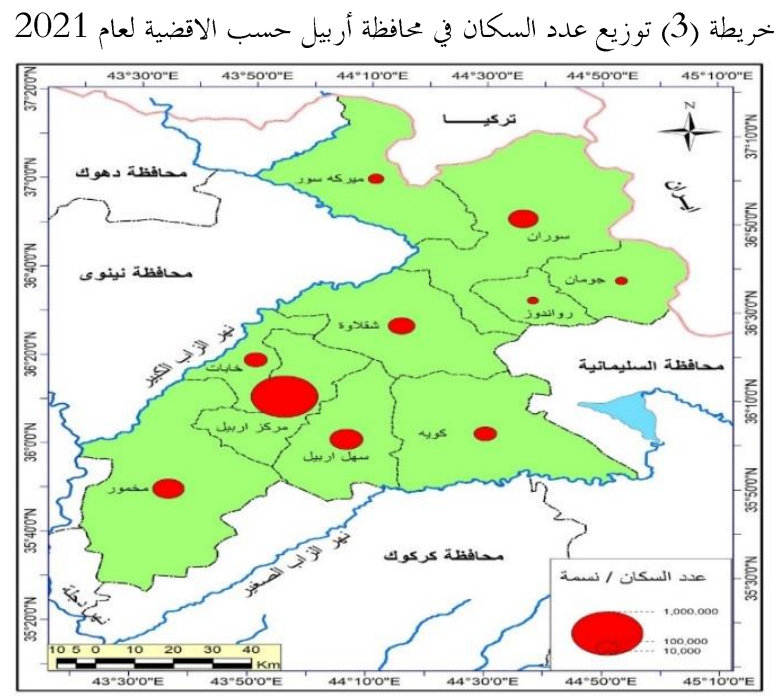

المصدر: من عمل الباحث بالاعتماد على جدول (3).

3-الاعلاف: هو أحد المحاصيل الموجودة في منطقة الدراسة هدف الحصول على المادة الخضراء كغذاء للماشية او بهدف الحصول على البذور او كليهما معا، من المحاصيل العلفية الموجودة في منطقة الدراسة هي الشعير والقمح والذرة الذي يقدم كعلف اخضر او حبوب او علف جاف المستخدم من سيقان نباتات الشعير والقمح اما نباتات الاعشاب الموجودة في منطقة الدراسة فهي متواجدة .مساحات كبيرة والتي تتغذى عليها الماشية في جميع فصول السنة سواء كانت خضراء ام بعد ان بجف(7). ويستخدم اغلب مربي الحيوانات المراعي الطبيعية في تغذية حيواناتم وهذا ما يساعدهم في توفير مبالغ من اجل تربية حيواناهم وان هذه الاعلاف تساعد الحيوانات في توفير الطاقة لأجسامها ومن اجل زيادة كمية اللحوم و الانتاج للحليب والاصواف و الجلود التي تدخل في كثير من الصناعات. 4-الخدمات البيطرية: يقصد ها الخلدمات التي توفرها المستشفيات و العيادات البيطرية للثروة الخيوانية وذلك من اجل مكافحتها للأمراض والآفات التي تصيب الثروة الحيوانية بمختلف انواعها، ويجب ان يكون تعاون بين الدوائر الزراعية والبيطرية ومربي الثروة الحيوانية من اجل القضاء على الامراض التي تصيب الحيوانات للنهوض بالثروة الحيوانية كما ونوعا عن طريق اعطائها العلاجات المناسبة الفعالة و اللقاحات الجيدة من اجل ادخال سلالة جديدة ذات انتاج جيد في منطقة الدراسة. حيث يوجد في منطقة الدراسة (27) مركزا بيطريا انظر جدول (4) حيث تتوزع على (10) اقضية من اقضية محافظة اربيل وتتباين توزيعها بين تلك الاقضية فبعض الاقضية يو جد فيها مركزا واحدا و بعضها يوجد ثلاث 
مراكز بيطرية وهي كما موضحة في الجلدول السابق ذكره. وان هذه المراكز تعد قليلة مقارنة مع اعداد الثروة الحيوانية في منطقة الدراسة.

\section{المبحث الثائ: التوزيع الجغغرافي للأبقار والاغنام والماعز في منطقة الدراسة:}

بعد ان استعرضنا الخصائص الطبيعية والبشرية في منطقة الدراسة وأثرها في الثروة الحيوانية في محافظة اربيل سنتطرق في هذا المبحث عن توزيع الحيوانات (الابقار والاغنام والماعز) كلا على حدا وتباينها حسب الاقضية و كثافتها في منطقة الدراسة.

1-الابقار: تعد الابقار واحدة من اهم الحيوانات الموجودة في منطقة الدراسة وبأنواع غختلفة منها الفريزي والهولندي وغيرها من الانواع الاخرى وتستخدم الابقار في انتاج اللحوم والحليب وان انتاجها

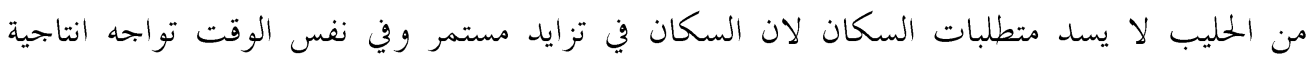

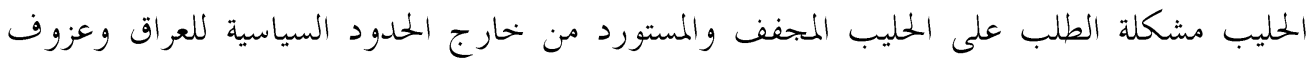
بعض السكان عن تناول الحليب المحلي الطازج. حيث أكد مدير الثروة الحيوانية في وزارة الزراعة في مني

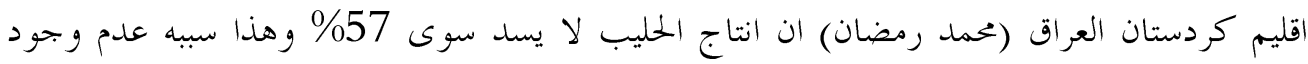
مشاريع عصرية وجعل الاقليم يعتمد على الحليب المستورد لسد 43\% من حاجته السته السنوية من الحليب. وبهذا فان اعداد الابقار في محافظة اربيل هي تسد حاجة السكان من اللحوم والحليب خاصة وان السكان في تزايد مستمر سنة بعد اخرى حيث بلغت اعداد الابقار في عام 2016 (102638) راس رساس

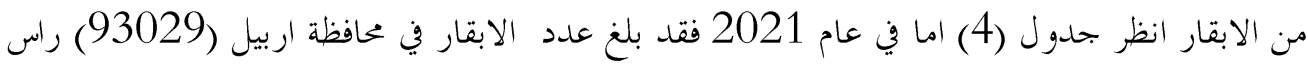

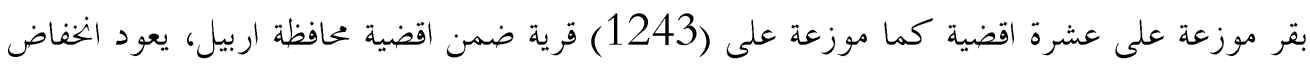

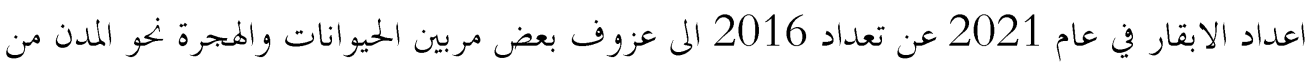
اجل البحث عن فرص عمل تدر لهم مبالغ مالية اكثر مما يكصلون عليها من تربية الثروة الحيوانية.

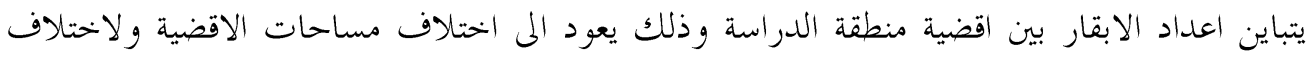
تو اجد الاعلاف والايدي العاملة وتضاريس كل قضاء حيث تصدر قضاء سوران المركز الاول في عدد الابقار البالغ (27554) راس من الابقار اما المركز الثنائ فقد احتله قضاء ميركه سور اما المركز الاخير

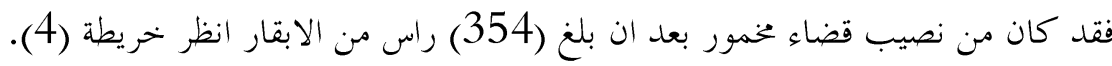

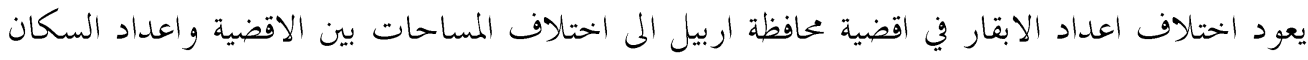
والايدي العاملة والى توفير المراعي والاعلاف لتلك الحيوانات فضلا عن تضاريس كل قضاء ومناخ كل 
قضاء فبعضها تتوفر فيه النباتات الطبيعية التي تتغذى عليها الابقار وخاصة في الاجزاء الشمالية والشمالية الشرقية.

2-الاغنام: تعد الاغنام واحدة من الحيوانات المهمة في العراق عامة ومنطقة الدراسة خاصة وذلك لما تمد الانسان بمنتجاتا المهمة من اللحوم والاصواف والحليب فهي توجد في منطقة الدراسة بأعداد كبيرة

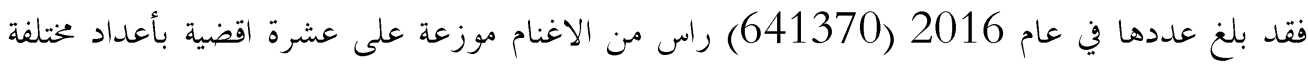
اما في عام 2021 فقد انخفضت اعدادها عما كان عليه في عام 2016 حيث علئ رلغت في في عام 2021 (631381) راس من الغنام وهي تتوزع على عشرة اقضية من محافظة اربيل، حيث تصدر قضاء شقلاوة اعداد الاغنام من بين اقضية المحافظة حيث بلغ (128111) راس من من الغنام اما المركز الثاني

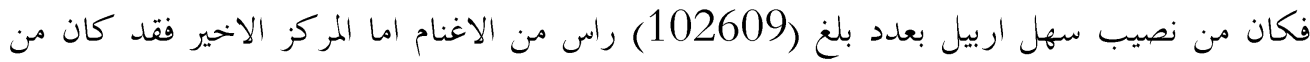
نصيب راوندوز ب(4160) راس من الاغنام انظر جدول (4) وخريطة (5). يعود هذا الاختلاف في اعداد الاغنام اللى اختلاف العوامل الطبيعية والبشرية بين اقضية منطقة الدراسة كما ان للعو امل الاجتماعية دورا بارزا في اختلاف اعداد الاغنام في منطقة الدراسة ما بين قضاء واخر.

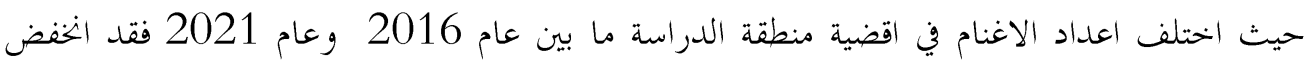

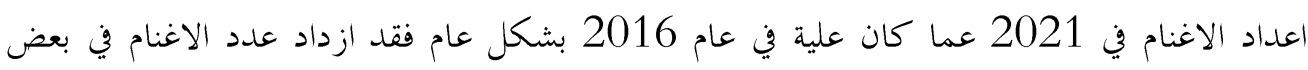
الاقضية والخفضت اعدادها في اقضية اخرى ما بين التعدادين وهذا ما لاحظناه في قضاء مركز اربيل الذي كان فيه اعداد الاغنام في عام 2016 (90208) وفي عام 2021 بلغ (52403) راس من من فين الاغنام وهذا ان دل على شيء انما يدل على توفر العوامل الجغغرافية في هذا القضاء الملائمة لتربية الاغنام

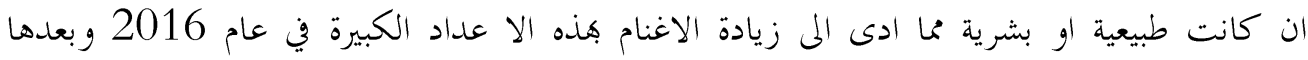
تدهورت بعض العوامل الجغرافية مما ادى هذا الانخفاض في اعداد الاغنام كما حصل هذا في قضاء راوندوز اما في قضاء سهل اربيل فقد كان العكس فقد ارتفعت عداد الاغنام في عام 2021 عما كان

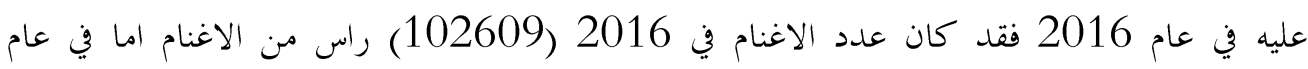
2021 فقد بلغ (140414) راس من الاغنام وهذا ايضا يعود الم اختلاف العوامل الجغغرافية ما بين التعدادين من حيث الاعلاف وتوفير المناخ المناسب والعوامل البشرية نغو تطور افضل لتربية الغنام في

منطقة الدراسة.

جدول (4): التوزيع الجغر افي للثروة الحيو انية في محافظة اربيل لعامي (2016 - 2021)

\begin{tabular}{|l|l|l|l|}
\hline 2021 & 2016 & الاقضية & \\
\hline
\end{tabular}




\begin{tabular}{|c|c|c|c|c|c|c|c|}
\hline الماعز & الاغنام & الابقار & الماعز & الاغنام & الابقار & & \\
\hline 72555 & 38046 & 27554 & 72570 & 39046 & 27500 & 3 & سوران \\
\hline 15356 & 4649 & 18358 & 15350 & 4640 & 13358 & 3 & ميركه سور \\
\hline 16955 & 6345 & 3711 & 6320 & 15356 & 18315 & 1 & جومان \\
\hline 25145 & 4175 & 3835 & 25140 & 4160 & 3820 & 1 & راوندوز \\
\hline 105731 & 128118 & 13167 & 105700 & 128111 & 13200 & 5 & شقلاوة \\
\hline 22037 & 52403 & 3402 & 30043 & 90208 & 11442 & 3 & مركز اربيل \\
\hline 38781 & 140414 & 12583 & 30775 & 102609 & 4543 & 3 & سهل اربيل \\
\hline 64457 & 93957 & 8540 & 64400 & 93970 & 8570 & 5 & كويه \\
\hline 16323 & 52503 & 1525 & 16200 & 52500 & 1515 & 2 & خابات \\
\hline 9594 & 110771 & 354 & 9549 & 110770 & 375 & 1 & مخمور \\
\hline 386934 & 631381 & 93029 & 376047 & 641370 & 102638 & 27 & المج \\
\hline
\end{tabular}

المصدر: وزارة الزراعة والموارد المائية، المديرية العامة للزراعة في محافظة اربيل، قسم الثروة الحيوانية، بيانات غير منشورة لعام .2021

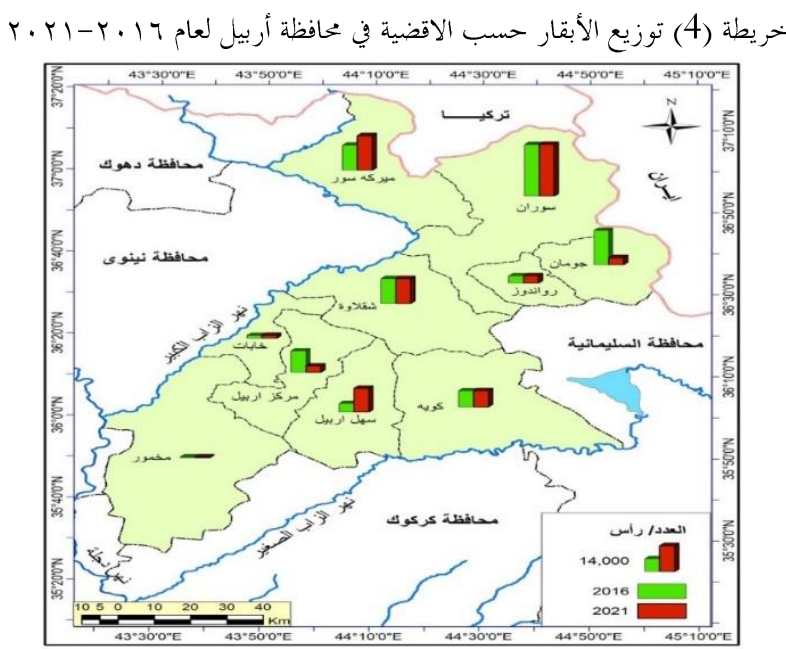

المصدر من عمل الباحث بالاعتماد على جدول (4).

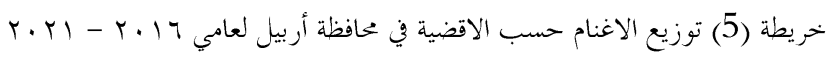




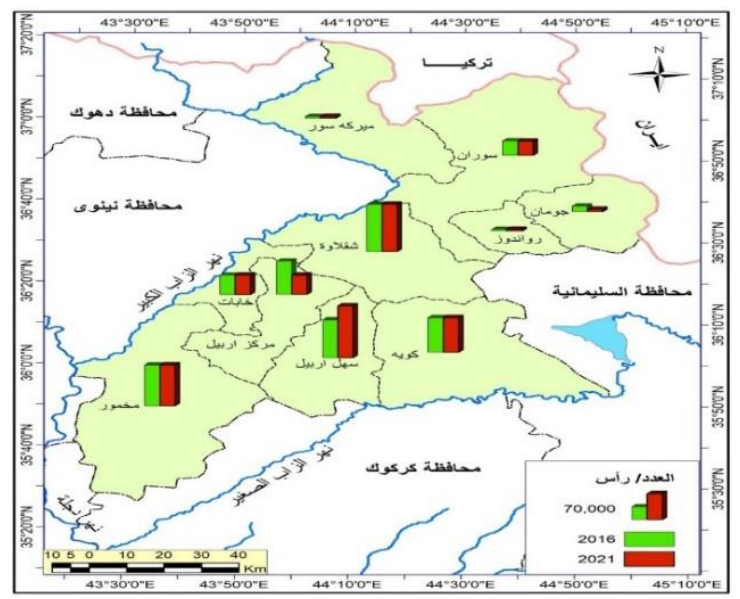

المصدر من عمل الباحث بالاعتماد على جدول (4).

3-الماعز: تحتل الماعز المرتبة الثانية بعد الاغنام من حيث اعدادها في منطقة الدراسة حيث بلغت (386934) راس من الماعز في عام 2021 بينما كان عددها (376047) راس في عام 2016 تبين من هذا ان اعداد الماعز ازدادت عما كان عليه في عام 2016 فقد تصدر اقضية منطقة الدراسة بأعداد الماعز هو قضاء شقلاوة ب(105731) راس من الماعز وجاء بالمرتبة الثانية قضاء سوران ب(72555) راس اما المركز الثالث كان من نصيب قضاء كويه بعدد بلغ (64457) راس من الماعز تدل هذه الزيادة في تلك الاقضية في اعداد الماعز المى توفر الظروف الجغرافية المناسبة من اجل تربية الماعز خاصة وان الماعز يمكن ان يعيش في مناطق المتضرسه و الوعرة على عكس الابقار والاغنام التي تعيش في

المناطق السهلية والقليلة التضرس و الوعورة. انظر صورة (1) اما من حيث اقل قضاء في تربية الماعز فقد كان من نصيب قضاء مخمور فقد بلغ (9594) راس من الماعز تو جد في قضاء مخمور لعام 2021انظر جدول (4) وخريطة (6) يعود الخفاض اعداد الماعز في بعض اقضية محافظة اربيل في قضاء مخمور الم قلة توفر النباتات الطبيعية وقلة الايدي العاملة التي تركت تربية الماعز وانصرفت الى تربية الاغنام والابقار التي ممكن ان تدر لهم ارباح اكثر من تربية الماعز مع عزوف بعض المدربين عن تربية الحيوانات وهجرهم من القرى نهو المدن من اجل البحث عن عمل داخل المدن يوفر لهم رؤوس اموال اكثر محا كانوا يعملون عليه في القرى. ان اختلاف اعداد الماعز ما بين عامين 2016 و 2021 يعود الى عوامل طبيعية وبشرية من حيث توفر الامطار التي توفر النباتات الطبيعية لتوفير الاعلاف لتلك الحيوانات مع ملائمة درجة الحرارة في بعض الاقضية واختلاف اعداد المربين ما بين التعدادين فضلا عن عامل الامن السياسي في اجزاء منطقة 
الدراسة الذي يلعب دورا اساسيا في تربية الثروة الحيوانية بمختلف انواعها وهجرة بعض المربين في عام 2021 عما كان عليه في عام 2016 كل هذه العو امل ادت الى اختلاف اعداد الماعز ما بين العامين. صورة (1) الماعز في المناطق المتضر سة

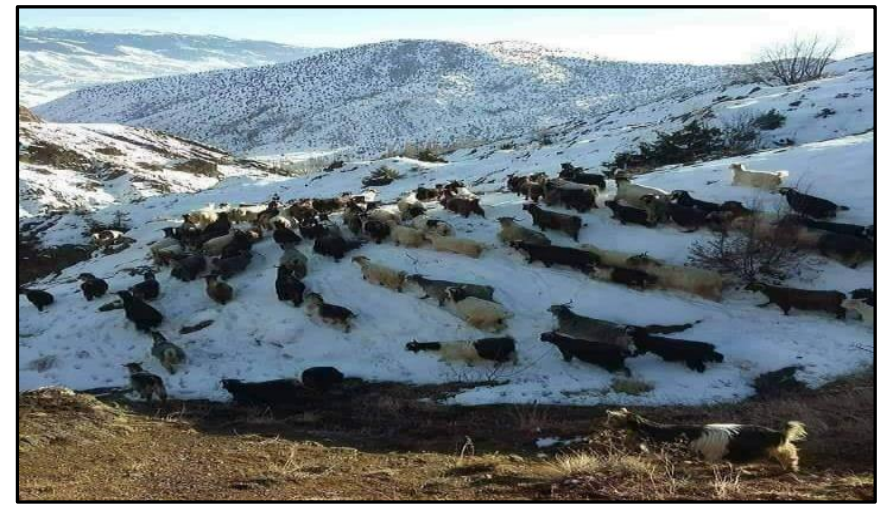

المصدر: التقطت هذه الصورة في 2021/1/26.

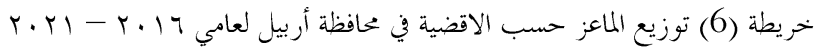

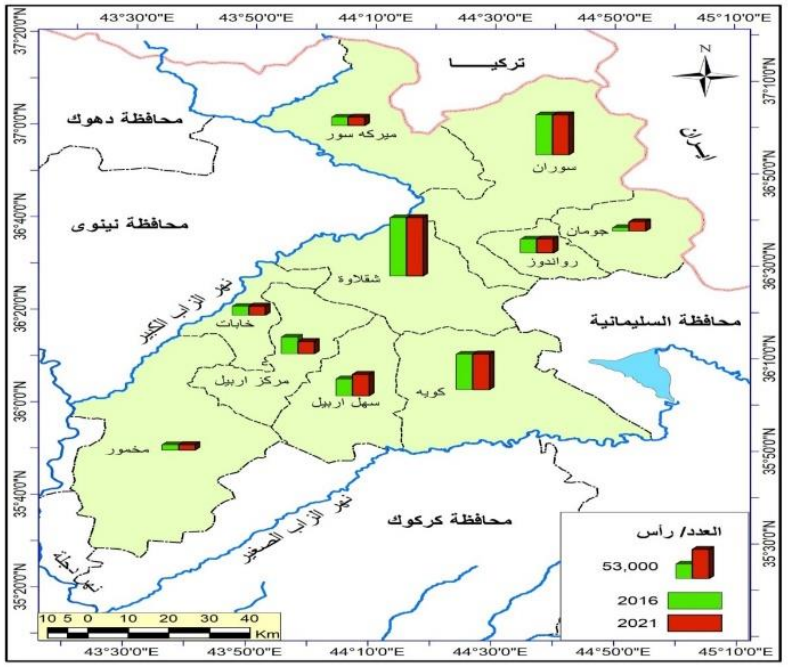

المصدر من عمل الباحث بالاعتماد على جدول (4). 
المبحث الثالث: المشاكل التي تواجه الثروة الحيوانية والحلول المقترحة لها في منطقة الدراسة تواجه الثروة الحيوانية بحموعة من المشاكل منها طبيعية ومنها بشرية نتيجة للإهمال او القصور او السياسات الحكومية غير المتوازنة في العراق عامة ومنطقة الدراسة خاصة من هذه المشاكل ما ئأتي: أ-المناخ: للمناخ دور فعال في تربية الثروة الحيوانية حيث ان اختلاف درجات الحرارة وله اثر في تربية الثروة الحيوانية اما الامطار فلها تأثير مباشر على تربية الثروة الحيوانية في منطقة الدراسة حيث ان سقوط الامطار تساعد على نمو النباتات والاعشاب في منطقة الدراسة وان تذبذب كمية الامطار في اي مكان تؤثر على النباتات ونوعها ان اغلب مربي الحيوانات يعتمدون على النباتات الطبيعية التي تنمو بعد

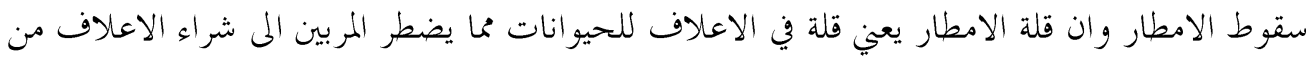
الاسواق لتغذية الحيوانات وهذا يادي المى زيادة تكلفة تربية الحيوانات ان بعض المربين يعتمد في تربية

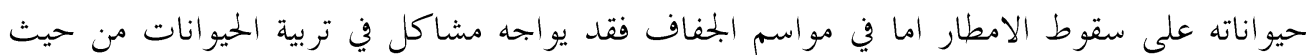
توفير الغذاء لها عن طريق تعويض تلك النباتات بشراء بعض الاعلاف بأسعار مرتفعة وهذا بلدوره يؤدي

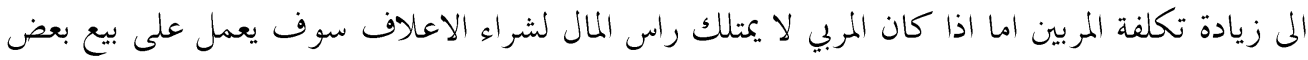
من الحيوانات لديه من اجل توفير راس المال لشراء الاعلاف للحيوانات الباقية لديه وفي بعض الاحيان يعمل المربين على رعي حيواناهم على ما موجود في المراعي من بقايا نباتات جافة وان قلة الاعلاف

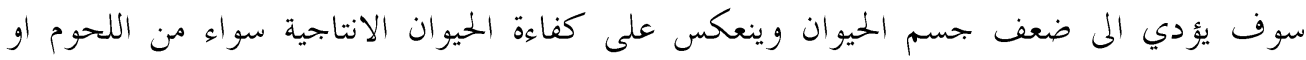

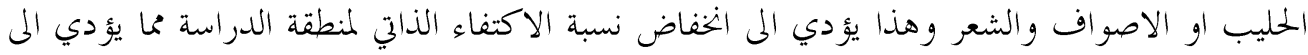
ارتفاع اسعار اللحوم ومشتقات الحليب وعدم كفايتها يضطر السكان الى جلبها من خارج حدود منطقة الدراسة لسد النقص الحاصل فيها. اما الثلوج التي تسقط على اغلب اجزاء منطقة الدراسة لها تأثير مباشر على تربية الثروة الحيوانية وخاصة

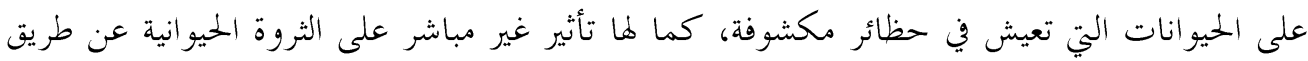
تأثيرها على النباتات التي تتغذى عليها الحيو انات صورة (2) لعين 


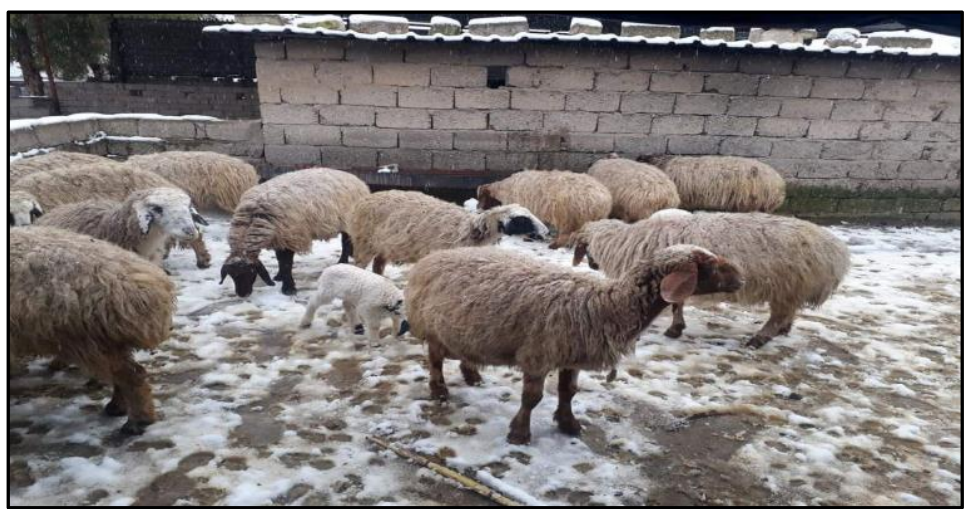

المصدر: التقطت هذه الصورة في 2021/1/27.

ب-الامر اض التي تصيب الحيوانات في منطقة الدراسة: ان الامراض التي تصيب حيوانات الابقار والاغنام والماعز عديدة وهي تفتك هما في بعض الاحيان وتؤدي الى موها وبعض الامراض يمكن علاجهها بسهولة وبعضها لا يعالج بسهولة وقد يحتاج الى مبالغ من اجل توفير العلاج المناسب لذلك المرض ومن هذه الامر اض ما يأتي: 1-الامراض الطفيلية: تصاب الحيو انات بالأمراض الطفيلية الداخلية مثل ديدان المعدة والامعاء والديدان الشريطية وديدان الكبد وديدان الرئة اما الطفيليات الخارجية كالجرب و القراد والقمل. 2-الحمى القلاعية: هو فايروس مرض القدم والفم بسبب تقرحات في الفم والقدم في الابقار وبعض الخيوانات وهو شديد العدوى للمو اشي ومن اعر اض هذا المرض -ارتفاع درجة حرارة الحيو ان لتتعدى 40 درجة - علدم القدرة على الخر كة - ققلة الطعام لدى الحيوان 3-انتفاخ الكرش الحاد عند الابقار: يهدث هذا المرض عند الابقار نتيجة التخمر الذي يهدث بالكرش ويؤدي المى بتمع الغازات في كرش الابقار ويعود سبب هذا المى الحيوان اكل الاعلاف الخضراء المبللة بالأمطار او الندى كالملفوف والشمندر العلفي او الذرة الخضراء الغير ناضجة، ووفي هذه الحالة يمنع الحيوان من تناول الماء لان شرب الماء يزيد من عملية الانتفاخ، ومن اهم اعراض هذا المرض تورم الجانب الايسر للحيو ان وقلة او عدم تناول الاعلاف مع صعوبة التنفس مع امتناع الحيوان عن الاجترار، يقوم الحيو ان بضرب بطنه عن طريق ارجله، اضافة الى ان الحيوان يبقى فمه مفتوحا. يمكن ان تعالج هذه 
الاصابة بعدة طرق يمكن سكب الماء على جسم الحيوان اذا كانت درجة الحرارة للجو مرتفعة، منع الحيو ان من تناول اي نوع من العلاف، العمل على سحب لسان الحيوان خارج الفم لعدة مرات وذلك بلك

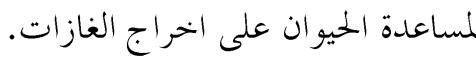
يعطى الحيو ان علاج ايكيستول 15 غراما مع فورمالين 10 او 15 غرام في نصف لتر ماء عن طريق الفم وذلك لتقليل الغازات ومنع تخمر الطعام(8). 4-التهاب المعدة: تصاب به الحيوانات عن طريق البكتريا وتصاب به الحيوانات طول العام اي ليس لها

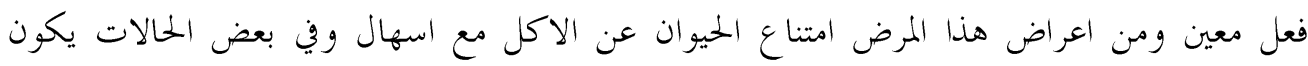

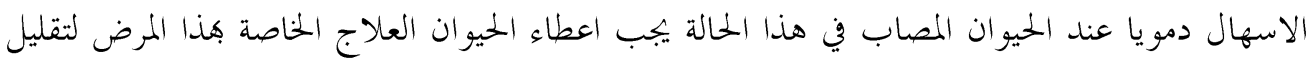
نسبة الاصابة. 5-مرض اللسان الازرق: هو أحد الامراض التي تصيب الاغنام والماعز ويمكن ملاحظته عن طريق

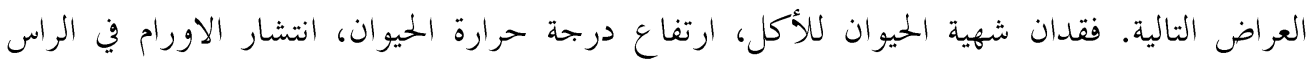
وجفون العين، تورم وازرقاق اللسان مع احتقان الفم وضهور سيل اللعاب من فم الحيوان.

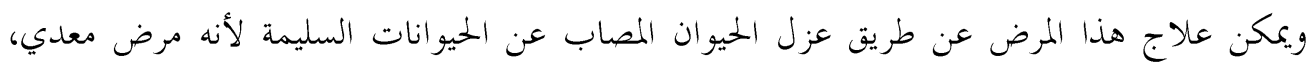

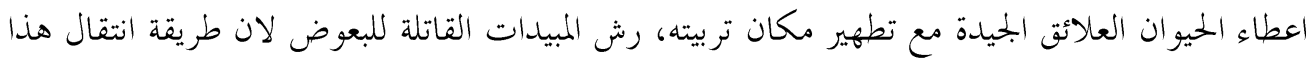
المرض هي عن طريق البعوض مع توفر بعض اللقاحات التي تعطي مناعة لجسم الحيوان.

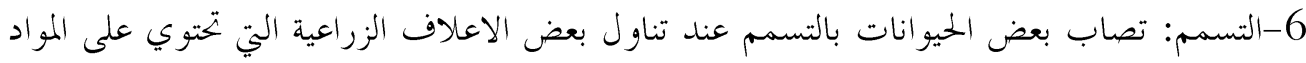

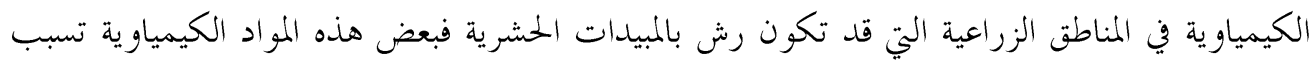

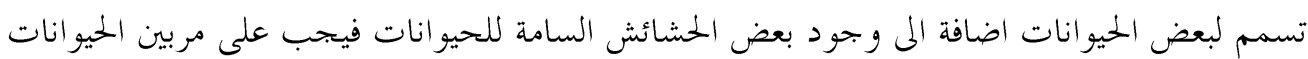

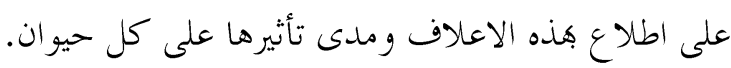

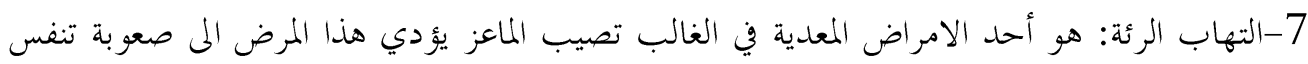

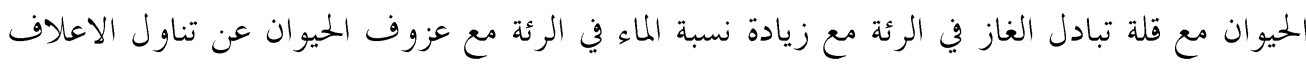

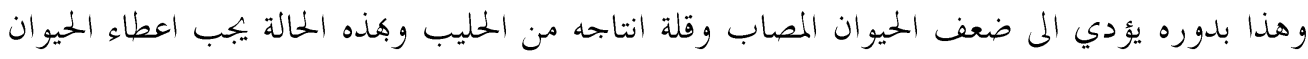
المصاب العلاجات الخاصة به وذلك لتفادي موت الحيوان مثل علاج سلفاديميدين و او كسيتتراسكلين عن طريق الحقن بالعضلة. 8-التهاب الفم البثري: يصيب هذا المرض الحملان ويسبب ضهور فقاعات ودمامل حول الفم وحول فتحت الانف ومن اعراض هذا المرض قلة الاكل مع صعوبة بلع الطعام وارتفاع في درجة الحرارة 
للحيوان وهو من الامراض المعدية. يمكن علاج هذا المرض عن طريق عزل الحيوان المصاب عن الحيوانات السليمة واعطائه الغذاء مع اعطائه بعض المراهم التي توضع على هذه الدمامل مع استخدام المقويات لرفع مناعة الحيو ان مع وضع بخاخ اليود الازرق على المناطق المصابة للتخلص من هذا المرض. 9-الحمى المالطية: يحدث هذا المرض بواسطة بكتريا البروسيلا وتؤثر هذه البكتريا على حئى حيوانات الاغنام والابقار، حيث تنتقل هذه البكتريا عن طريق الفم اثناء الاكل او عن طريق اللمس ويسبب هذا المرض الاجهاض للحيوانات وخاصة في الاشهر الاخيرة من الحمل يؤدي هذا المرض الم احتباس المشيمة والتهاب الرحم(9)، يمكن علاجها عن طريق المضادات الحيوية. 10-عسرة الو لادة: يحدث هذا المرض عن طريق نقص المع المواد او الهرمونات او الفيتامينات لدى الجنين. ويؤدي هذا المى زيادة وزن الجنين او تشوهات الجنين او وضع الجنين في رحم الام غير صحيح. هذا ما

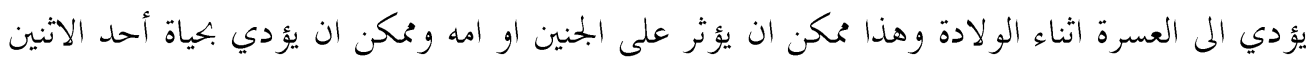
(الام - الجنين) وقد يؤدي بموت الاثنين معا. ح-قلة الحدمات البيطرية: يعاني مربون الثروة الحيوانية من قلة الخحدمات البيطرية المقدمة للثروة الحيوانية

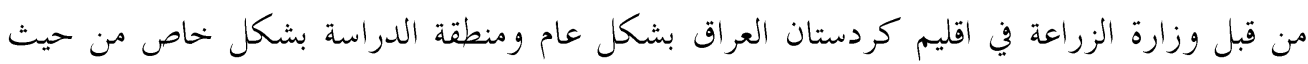
دعم مربي الثروة الحيوانية بالعلاجات واللقاحات والارشاد الطي ومكافحة الامراض التي تصيب الثروة

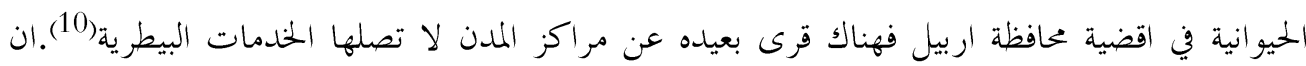

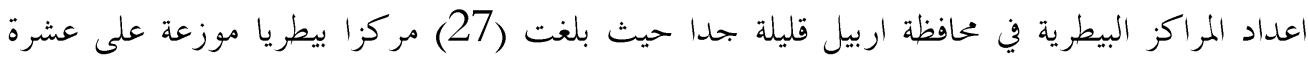
اقضية ضمن منطقة الدراسة لعام 2021. خ-الايواء (الحظائر): تعد حضائر الحيوانات من الامور الاساسية لتربية الثروة الحيوانية وفي عملية

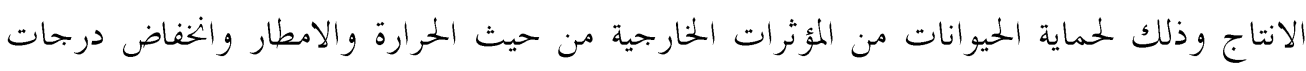
الحرارة ونزول الثلج في منطقة الدراسة كل هذا يجب ان يأخخذ بالحسبان عند عمل حضائر للحيو انات.

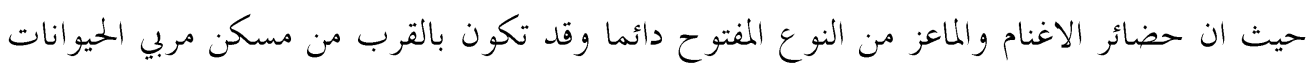

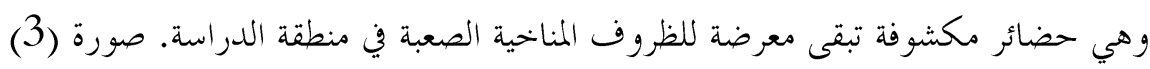

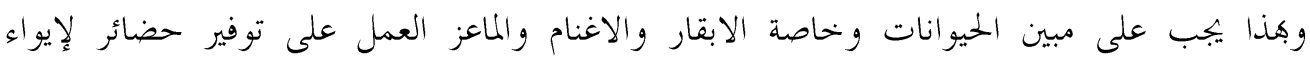
الحيوانات وحمايتها من المؤثرات الخارجية.

صورة (3) حضائر الحيوانات المفتوحة 


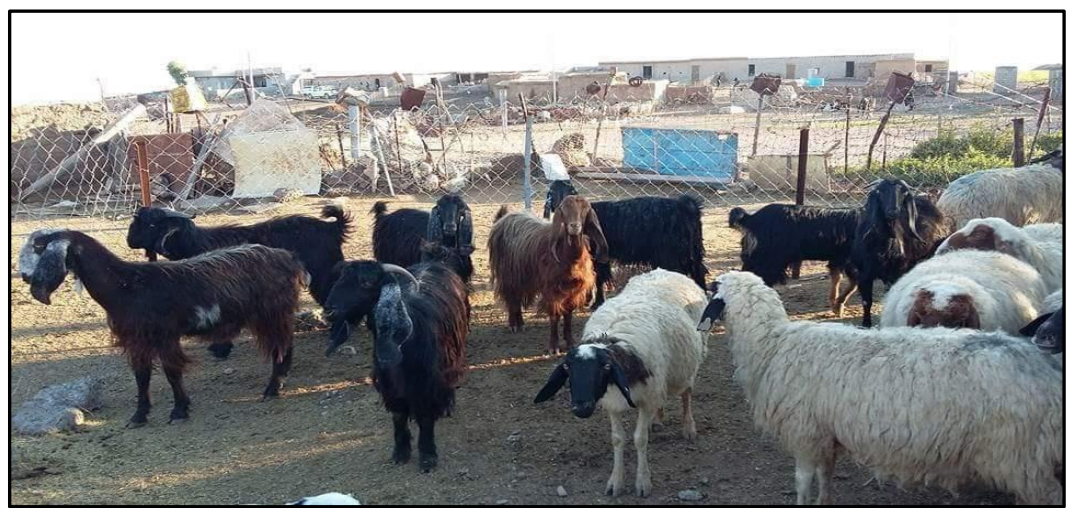

المصدر: التقطت هذه الصورة في 2021/5/14.

د-قلة الوعي لدى مربين الحيوانات: ان قلة الوعي للى مربين الثروة الحيوانية قد يفتك بالثروة الحيوانية فيجب على الارشاد الزراعي عمل برامج تثقيفية لمربين الحيوانات مع عمل غرف جوالة في القرى لتدريب مربين الحيوانات لان اغلب المربين يعانون من قلت الوعي من حيث كيفية تربية الحيوانات و نظافة الحضائر ولمعرفة الامراض التي تصيب الحيوانات وكيفية معالجتها من اجل النهوض بالثروة الخيو انية في منطقة الدراسة. ذ-هريب الثروة الحيوانية: وهي أحدث المشاكل التي تواجه الثروة الحيوانية في العراق عامة ومنطقة الدراسة خحاصة، حيث ان قريب الثروة الحيوانية وخاصة الاغنام الى خارج حدود البلاد هي مشكلة كبيرة خاصة بعد عام 2003 بعد سقوط الحكومة فقد ازدادت هذه العملية وهي مستمرة المى يومنا هذا مع الدول المجاورة للعراق مثل ايران وسوريا وتركيا ومن المشاكل النابجة عن هذه العملية هي قلت اعداد الثروة الحيوانية في منطقة الدراسة مع ارتفاع اسعار كيلو اللحم الذي يصل الى (14) الف دينار مع انخفاض انتاجية الحليب ومشتقاته. علما ان عملية التهريب ورائها جهات واحزاب سياسية هذا ما اكده أحد نواب البرلمان من اقليم كردستان (حمه صالح) ومن اسباب هذا التهريب هو فارق السعر مع ضعف الاجراءات الامنية على الحلدود العراقية مع الدول المجاورة.

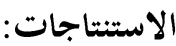

1- تعاني الثروة الحيوانية في محافظة اربيل من انتشار الامراض وقلة الدعم الحكومي لمربين الثروة الحيو انية. 
2- تردي الخدمات البيطرية في منطقة الدراسة من خلال عدد المراكز البيطرية البالغة (27) مركز بيطري فتط.

3- أكثر الحيوانات انتشارا في منطقة الدراسة هي الاغنام ومن ثم الماعز وبعدها الابقار (631381)

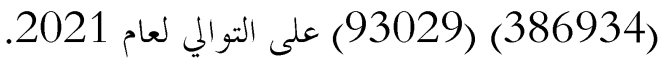

4- ارتفاع اعداد الثروة الحيوانية في بعض الاقضية ضمن منطقة الدراسة يعود الى وجود المراعي و المساحات الكافية لتربيتها وخاصة الاغنام في هولير وشقلاوه. 5- تقع منطقة الدراسة ضمن مناخ البحر المتوسط الذي يمتاز بدرجات حرارة معتدلة وسقوط امطار شتوية تكفي لنمو النباتات.

6- ان منطقة الدراسة تقع ضمن مناطق مضمونة المطر وهي تزرع الزراعة الديمية على الامطار. 7- سعة مساحة المراعي الطبيعية في بعض اقضية منطقة الدراسة.

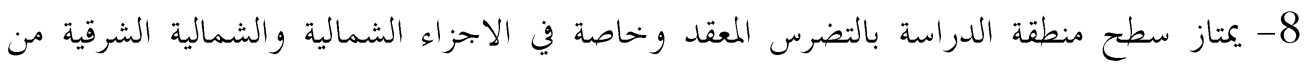
منطقة الدراسة. 9- تر يب بعض الحيوانات خارج الحدود العراقية وخاصة الاغنام.

التوصيات:

1- توفير الاعلاف وزراعة المحاصيل العلفية من قبل وزارة الزراعة في منطقة الدراسة ومن اجل اعطائها للمربين بأسعار رمزية من اجل درعم دعم المربين.

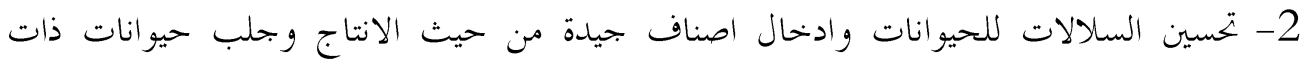
اصناف محسنة لرفع كفاءتا في منطقة الدراسة.

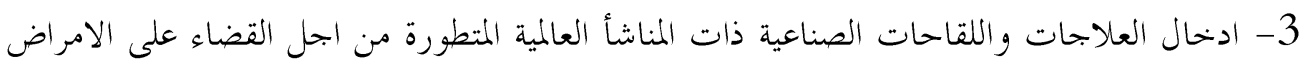

$$
\text { التي تصيب الخيوانات. }
$$

4- العمل على تشكيل مر اكز لبحوث الثروة الحيوانية للعمل على حل المشاكل القائمة في البلاد بشكل عام ومنطقة الدراسة بشكل خاص. 5- يجب التعاون ما بين دوائر الزراعة والمراكز البيطرية وكليات الزراعة من اجل تطوير تربية الثروة الحيوانية ورفع كفاءة الخريجين العاطلين عن العمل لتأهيلهم لتربية وادارة الثروة الحيو انية.

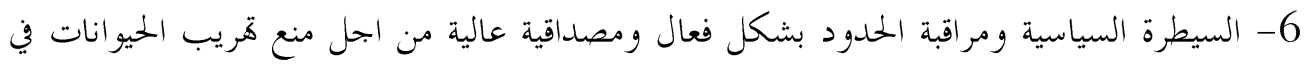

$$
\text { عموم العراق. }
$$


7- زيادة اعداد الكو ادر البيطرية مع زيادة المراكز البيطرية في منطقة الدراسة من اجل سد احتياجات

$$
\text { المربين من الخلدمات البيطرية. }
$$

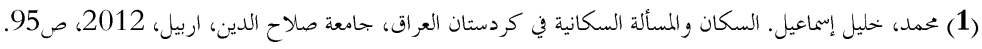

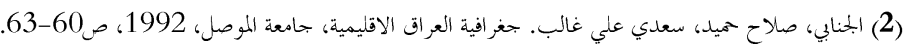

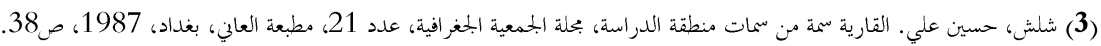

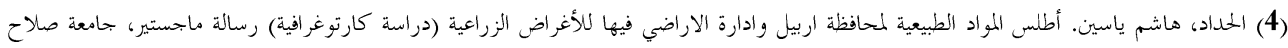

$$
\text { الدين، ص50. }
$$

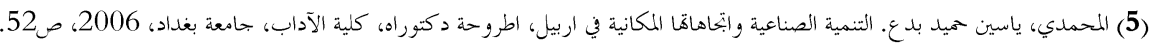

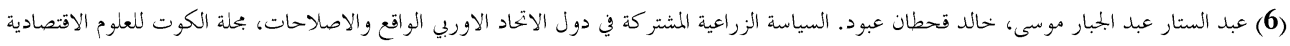

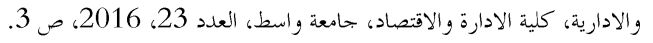

$$
\text { (7) الدراسة الميدانية للباحث للمدة } 10 \text { - 2021/5/15. }
$$

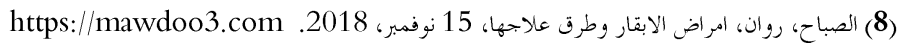

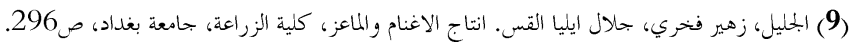

(10) المقابلات الشخصية مع عدد من مربي الثروة الحيوانية في بعض قرى منطقة الدراسة للمدة من 10-2021/5/15. 